\title{
A NOVEL RHODAMINE-BASED FLUORESCENCE CHEMOSENSOR CONTAINING POLYETHER FOR MERCURY (II) IONS IN AQUEOUS SOLUTION
}

Wenqi Du, Yu Cheng, Weixin Shu and Zhengjian Qi*

College of Chemistry and Chemical Engineering, Southeast University Road 2, Jiangning District 211189, Nanjing, Jiangsu Province, P.R. China

Recebido em 03/12/2016; aceito em 29/03/2017; publicado na web em 01/06/2017

\begin{abstract}
A novel rhodamine-based $\mathrm{Hg}^{2+}$ chemosensor P2 containing polyether was readily synthesized and investigated, which displayed high selectivity and sensitivity for $\mathrm{Hg}^{2+}$. Because of good water-solubility of polyther, the rhodamine-based chemosensor containing polyether can be used in aqueous solution. The sensor responded rapidly to $\mathrm{Hg}^{2+}$ in pure water solutions with a 1:1 stoichiometry. Meanwhile, it indicated excellent adaptability and also the responsiveness.
\end{abstract}

Keywords: rhodamine B; polymer; chemosensor; mercury ion.

\section{INTRODUCTION}

Various transition-metal ions are crucial for the life of organisms. Mercury is a not only dangerous but also hazardous toxic which has posed a great threat to our environment. ${ }^{1-4}$ Nowadays, average daily human intake of $\mathrm{Hg}^{2+}$ is nearly $20 \sim 30 \mu \mathrm{g}$ and more seriously is 200 300 $\mu \mathrm{g}$. This toxic ion species is a widespread industrial pollutant and make a serious influence on our health. Different speciation mercury can penetrate our environment by various ways, such as methyl mercury produced by aquatic microbes which accumulates through the food chain and oxidation of mercury vapor in atmosphere to water-soluble $\mathrm{Hg}^{2+}$ ions. ${ }^{5,6}$ It will have a serious effect on human's health after long-term exposure in this environment, which will lead to nausea, vomiting, abdominal pain, renal dysfunction and other diseases. The best way to detect $\mathrm{Hg}^{2+}$ that has gone into the food chain or contaminated the environment is to monitor the extent of mercury present in microorganisms such as bacteria, which survive in waste water or effluents.?

In recent decades, many methods have been developed to apply to mercury detection including graphite furnace atomic absorption spectrometry, atomic emission spectrometry, inductively coupled plasma atomic emission spectrometry and electrochemical methods. ${ }^{8-12}$ The major disadvantages of these detection techniques are expensive and time-consuming. Conversely, optical detection gives its priority to easy operability and high sensitivity. Great changes in absorption and fluorescent spectra of many compounds after interacting with the metal ions, so fluorescence analytical methods are effective and efficient ways to detect ions. ${ }^{13-15}$

Rhodamine B and its derivatives (RBHs) are well-known for their desirable properties, including good photostability, high extinction coefficient, and high fluorescence quantum yield, particularly in its nucleotide and nucleic acid conjugates. ${ }^{16}$ While some rhodaminebased chemosensors for $\mathrm{Hg}^{2+}$ ions have been reported, ${ }^{17-22}$ dual colorimetric and fluorescent chemosensors for $\mathrm{Hg}^{2+}$ were still rare ${ }^{23}$ and some of them were not efficient enough to be selective toward $\mathrm{Hg}^{2+}$ or sensed it in solvents. While, some of them were operated in organic solvents or in aqueous solution of organic solvent, which limit their applications in organism. ${ }^{24-28}$ Hence, the development of novel pure water soluble, sensitive and interference-free fluorescent chemosensors for $\mathrm{Hg}^{2+}$ detection is still highly desired. Poly(ethylene

*e-mail: qizhengjian506@163.com glycol) methyl ether[PEG], which is a well-known nontoxic, flexible, and excellent water-soluble polymer, is widely used in pharmaceutical, cosmetic, food processing and other industries. ${ }^{29-32}$ So PEG provides a feasible way to enhance the water solubility of rhodamine.

Here, we report a novel water-soluble and turn-on rhodaminebased caprolactam derivatives as a chemosensor for $\mathrm{Hg}^{2+}$ incorporating with poly (ethylene glycol) methyl ether (PEG), when binding phenomena could be probed through binding-induced changes in an electronic spectral pattern. Firstly, the hydrophilic polyether could reduce aggregation-caused quenching when rhodamine dyes tend to aggregate at high concentrations. Secondly, after RBH anchored in the PEG, the fluorescence experiments of this probe were performed in a pure aqueous solution, which is different from other probes determined in organic solvent or mixed solutions. We have designed this structure based on the idea that it is well-known that mercury ion is a soft-acid, it has been found that mercury ion is inclined to have a coordination sphere containing $\mathrm{N}$ and $\mathrm{O}$. On the other hand, the Schiff base structure provides a good ligand for mercury ion. The rhodamine-B acts as fluorophore which is covalently attached to polyether aromatic compound containing the heterocyclic nitrogen atoms. What's more, polyether aromatic compound has greatly enhanced the solubility of rhodamine B derivative. Sensor P2 was shown in Scheme 1.

\section{EXPERIMENTAL}

\section{Apparatus}

Fluorescence spectra measurement were performed on Horiba Jobin Yvon Inc. Fluorolog 3-TSCPC (Under the experiment conditions, all the excitation and emission silts are $5 \mathrm{~nm}$ ). ${ }^{1} \mathrm{H}$ NMR spectrum was run on a Bruker $300 \mathrm{MHz}$ spectrometer using TMS as the internal standard. Mass spectrum was recorded with a VG ZABHS double focusing mass spectrometer. Absorption spectra were measured on a UV-2201 double-beam UV/VIS spectrometer (All the measurements were conducted at room temperature).

\section{Materials}

All the materials for synthesis were purchased from Sinopharm Chemical Reagent Co., Ltd (Shanghai, China) and used without 
<smiles>CCN(CC)c1ccc2c(c1)Oc1cc(N(CC)CC)ccc1C2c1ccccc1C(=O)O</smiles><smiles>CN(N)C(C)(C)N</smiles><smiles>CC(C)(O)COC(C)(C)C</smiles><smiles>O=Cc1ccc(C(=O)O)cc1</smiles><smiles>CCN(CC)c1ccc2c(c1)Oc1cc(N(CC)CC)ccc1C21c2ccccc2C(=O)N1N</smiles>

RBII<smiles>COCCOC(=O)c1ccc(C=O)cc1</smiles>

PI<smiles>CCN(CC)c1ccc2c(c1)Oc1cc(N(CC)CC)ccc1C21c2ccccc2C(=O)N1N</smiles>

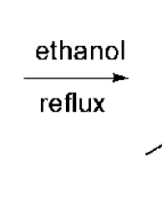<smiles>CCN(CC)c1ccc2c(c1)Oc1cc(N(CC)CC)ccc1C21c2ccccc2C(=O)N1/N=C/c1ccc(C(=O)OC(C)COC(C)(C)C)cc1</smiles>

$\mathrm{P} 2$

Scheme 1. The synthetic route of probe P2

further purification. Poly (ethylene glycol) methyl ether with the number average molecular weight of 350 and degree $98.0 \%$ was purchased from Energy Chemical company and dried in vacuum for $24 \mathrm{~h}$ before use. The solutions of metal ions were prepared from their analytical grade nitrate salts. The solutions of metal ions were prepared as $0.2 \mathrm{mmol} \mathrm{L}^{-1}$ in water solution.

\section{Synthesis of Rhodamine B hydrazide( $R B H)$}

As for the synthesis of RBH, several different procedures have been reported. ${ }^{33-35}$ In this study, $\mathrm{RBH}$ was synthesized by a modified method according to Xiang(yield: $81.0 \%){ }^{36} \mathrm{~m} / \mathrm{z}: 457.3\left([\mathrm{M}+\mathrm{H}]^{+}\right) ; \mathrm{M}^{+}$ calculated 456.3. IR(KBr, cm $\left.{ }^{-1}\right): v=3428,2987,2926,1689,1614$, 1514, 1380, 1218, 1117, 818, 767. ${ }^{1} \mathrm{H}$ NMR (400 MHz, $\mathrm{CDCl}_{3}$, $\delta \mathrm{ppm}), \delta(\mathrm{ppm}): 1.17(\mathrm{t}, \mathrm{J}=7.0 \mathrm{~Hz}, 12 \mathrm{H}), 3.34(\mathrm{q}, \mathrm{J}=7.0 \mathrm{~Hz}, 8 \mathrm{H})$, $3.62(\mathrm{~s}, 2 \mathrm{H}), 6.27$ (d, J=2.8Hz, 1H), 6.30 (d, J=2.4Hz, 1H), 6.43(d, $\mathrm{J}=2.4 \mathrm{~Hz}, 2 \mathrm{H}), 6.45(\mathrm{~d}, 2 \mathrm{H}), 7.11(\mathrm{~m}, 1 \mathrm{H}), 7.42(\mathrm{~d}, 1 \mathrm{H}), 7.44(\mathrm{~d}, 1 \mathrm{H})$, $7.93(\mathrm{~m}, 1 \mathrm{H})$.

\section{Synthesis of P1}

P1 was synthesized according to the esterification reaction. To $100 \mathrm{~mL}$ flask, 4-carboxybenzaldehyde (1.5 g, $0.01 \mathrm{~mol})$ and poly (ethylene glycol) methyl ether $(3.5 \mathrm{~g}, 0.01 \mathrm{~mol})$ were dissloved in $50 \mathrm{~mL}$ of dimethyl formamide (DMF). Then dimethylaminopyridine (DMAP) (0.122 g, $0.001 \mathrm{~mol})$ and N, N-diisopropylcarbodiimide (DIC) $(1.26 \mathrm{~g}, 0.01 \mathrm{~mol})$ were added into the flask. The reaction was carried out by reflux for $48 \mathrm{~h}$ when the color of solution finally turned yellow into brownish red. In order to remove dimethyl formamide from product, a large amount of saturated salt water was prepared to add into flask. Then the solution changed into turbid solution, and along with a large white precipitate was dissolved out. After filtration, faint yellow filter liquor was extracted by diethyl ether. The resulting product is finally dried under vacuum at room temperature after the aqueous phase conducted reduced pressure distillation. Yield: $50.0 \%$. FT-IR of P1(KBr), $\mathrm{cm}^{-1}$ : 3271, 2971, 2865, 1722, 1629, 1551, 1463, $1359,1322,1167,1120,850 .{ }^{1} \mathrm{H}$ NMR of P1 $\left(400 \mathrm{MHz}, \mathrm{CDCl}_{3}\right),(\delta$, ppm): 9.98(s, -CHO), 7.85(m, ArH), 7.72(m, ArH), 3.37-4.30(m, $\left.-\mathrm{CH}_{2}\right), 3.24\left(\mathrm{~m},-\mathrm{CH}_{3}\right)$.

\section{Synthesis of $\mathbf{P 2}$}

RBH $(0.5 \mathrm{mmoL}, 0.240 \mathrm{~g})$ was dissolved in $30 \mathrm{~mL}$ ethanol, and then polymer P1 ( $0.5 \mathrm{mmoL}, 0.241 \mathrm{~g})$ was slowly added. The mixture was stirred and refluxed for $12 \mathrm{~h}$ at $80^{\circ} \mathrm{C}$. After distillation in vacuum, the residue was recrystallized with methanol to give the final product P2. Yield: $52.0 \% .{ }^{1} \mathrm{H}$ NMR of $\mathrm{P} 2\left(400 \mathrm{MHz}, \mathrm{CDCl}_{3}\right),(\delta$, ppm): 1.17 (t, J=7.0 Hz, $\mathrm{NCH}_{2} \mathrm{CH}_{3}, 3.24$ (q, J=7.0 Hz, $-\mathrm{CH}_{3}$ ), 3.34 (q, $\left.\mathrm{NCH}_{2} \mathrm{CH}_{3}\right), 3.80-4.50$ (m, $-\mathrm{CH}_{2}$ ), 6.46 (d, J=2.4HZ, Xanthene-H), 6.42 (d, J=2.4 Hz, Xanthene-H), 6.29 (d, J=2.8 Hz, Xanthene-H), 7.93 (m, ArH), 7.45 (m, ArH), 7.11 (m, ArH), 7.7 (m, ArH), 8.0 (m, $\mathrm{ArH}), 8.1(\mathrm{~s},-\mathrm{CH})$.

\section{RESULT AND DISCUSSION}

The structures of compounds RBH, P1 and P2 were characterized by ${ }^{1} \mathrm{H}-\mathrm{NMR}$, IR and HR-MS. The results were in good agreement with the structure. Fluorescence and UV-vis studies were performed using the $2 \times 10^{-5} \mathrm{~mol} / \mathrm{L}$ solution of $\mathrm{P} 2$ in an aqueous solution with appropriate amounts of metal ions.

\section{Metal ion selectivity and competition experiments}

The selectivity of probe P2 toward different metal ions was 

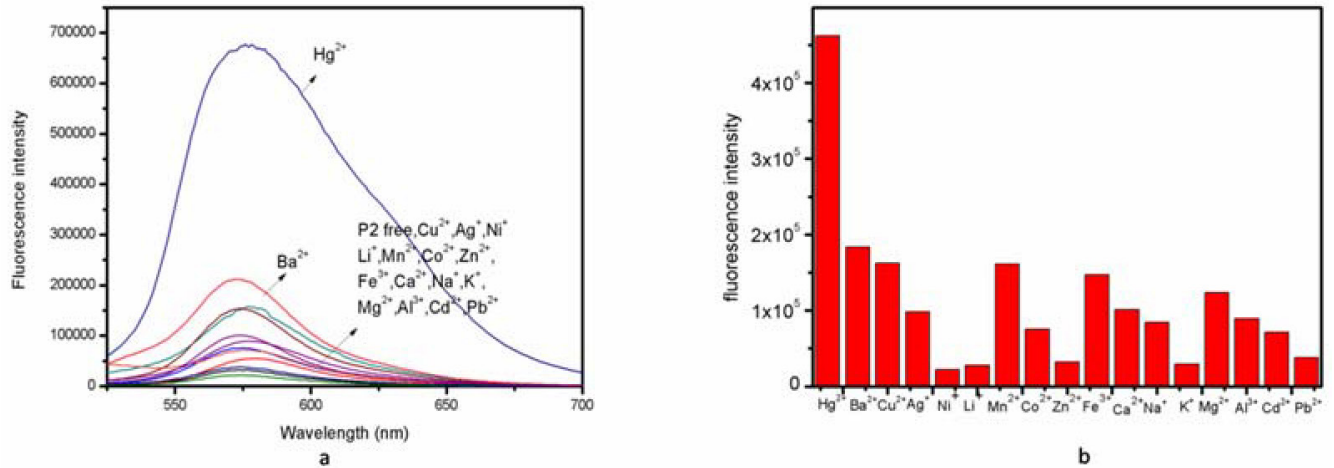

Figure 1. (a) Fluorescence spectra of P2 (10 $\mu \mathrm{mol} / \mathrm{L})$ in aqueous solution the presence of 10 equiv. of various metal ions; (b) Fluorescence intensity of P2 $\left(10 \mu \mathrm{mol} \mathrm{L}^{-1}\right)$ in aqueous solution the presence of 10 equiv. of various metal ions

conducted as shown in Figure 1. Probe P2 show a weak fluorescence in the absence of metal ions. On the addition of 10 eqiv. metal ions, the fluorescence intensity has changed. It is obvious that when 10 eqiv. $\mathrm{Hg}^{2+}$ was introduced into a solution of $\mathrm{P} 2$ in pure water, the fluorescence intensity increased. However, under the same condition, other metal ions such as $\mathrm{Fe}^{3+}, \mathrm{Zn}^{2+}, \mathrm{Mg}^{2+}, \mathrm{Ca}^{2+}, \mathrm{Cd}^{2+}, \mathrm{Cu}^{2+}, \mathrm{Pb}^{2+}, \mathrm{Ni}^{2+}$, $\mathrm{Mn}^{2+}, \mathrm{K}^{+}, \mathrm{Li}^{+}, \mathrm{Ag}^{+}, \mathrm{Al}^{3+}, \mathrm{Co}^{2+}$ and $\mathrm{Na}^{+}$, except for $\mathrm{Ba}^{2+}$, did not show remarkable changes in fluorescence intensity and color. Therefore, these phenomena indicated that probe $\mathrm{P} 2$ has an excellent selectivity towards $\mathrm{Hg}^{2+}$ in aqueous solution served as an "off-on" chemical sensor. Furthermore, we determined if probe $\mathrm{P} 2$ can recognize $\mathrm{Hg}^{2+}$ when it coexists with other metal ions in virtue of competition experiments. As shown in Figure 2, metal ions competiton experiments have conducted, which indicates the background metal ions showed very low interference with the detection of $\mathrm{Hg}^{2+}$ in the pure water solution.

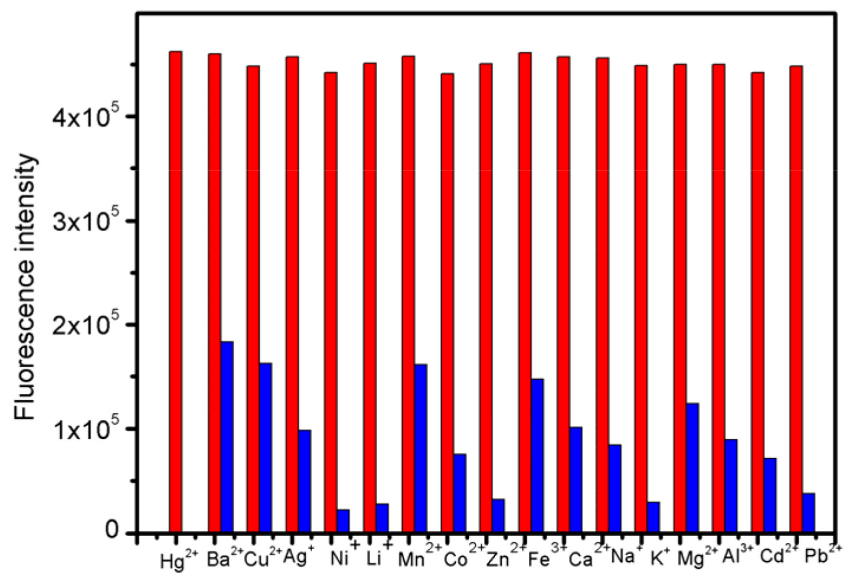

Figure 2. Fluorescence intensity (at $580 \mathrm{~nm}$ ) of P2 upon the addition of

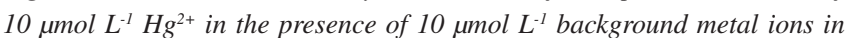
aqueous solution (Red bar: $\mathrm{P} 2+$ competing ions $+\mathrm{Hg}^{2+}$ Blue bar: $\mathrm{P} 2+$ competing ions)

\section{Emission spectra and detection limit of sensor P2}

As shown in Figure 3, UV-vis spectrum of compound P2 $\left(2 \times 10^{-5} \mathrm{~mol} \mathrm{~L}^{-1}\right)$ exhibited only very weak bands over $450 \mathrm{~nm}$, which could be attributed to the presence of a trace amount of the ring-opened form of compounds. On addition of 10 equiv. $\mathrm{Hg}^{2+}$ into solution, P2 immediately resulted in a significant enhancement of absorbance at about $560 \mathrm{~nm}$ simultaneously the color changed into light rose red. Other metal ions such as $\mathrm{Zn}^{2+}, \mathrm{Mg}^{2+}, \mathrm{Ca}^{2+}, \mathrm{Cd}^{2+}, \mathrm{Cu}^{2+}$, $\mathrm{Pb}^{2+}, \mathrm{Ni}^{2+}, \mathrm{Mn}^{2+}, \mathrm{K}^{+}, \mathrm{Li}^{+}, \mathrm{Ag}^{+}, \mathrm{Co}^{2+}, \mathrm{Fe}^{3+}$ except for $\mathrm{Ba}^{2+}$, did not show any significant color and spectral change. These phenomena suggest that these compounds can serve as "naked-eye" chemosensor for $\mathrm{Hg}^{2+}$. The spectral properties of sensor P2 were examined by Fluorolog 3-TSCPC and fluorescence titrations. Fluorescence spectra of $\mathrm{Hg}^{2+}$ titration were shown in Figura 4. Sensor P2 $\left(1 \times 10^{-5} \mathrm{~mol} \mathrm{~L}^{-1}\right)$ has a very weak fluorescence emission at about $560 \mathrm{~nm}$ with excitation at $500 \mathrm{~nm}$. Upon addition of $\mathrm{Hg}^{2+}$ (0-1.1 equiv), it displays a remarkable enhancement of fluorescence intensity, which is saturated by 1.4 equiv. of $\mathrm{Hg}^{2+}$ with about 9 -fold increase.

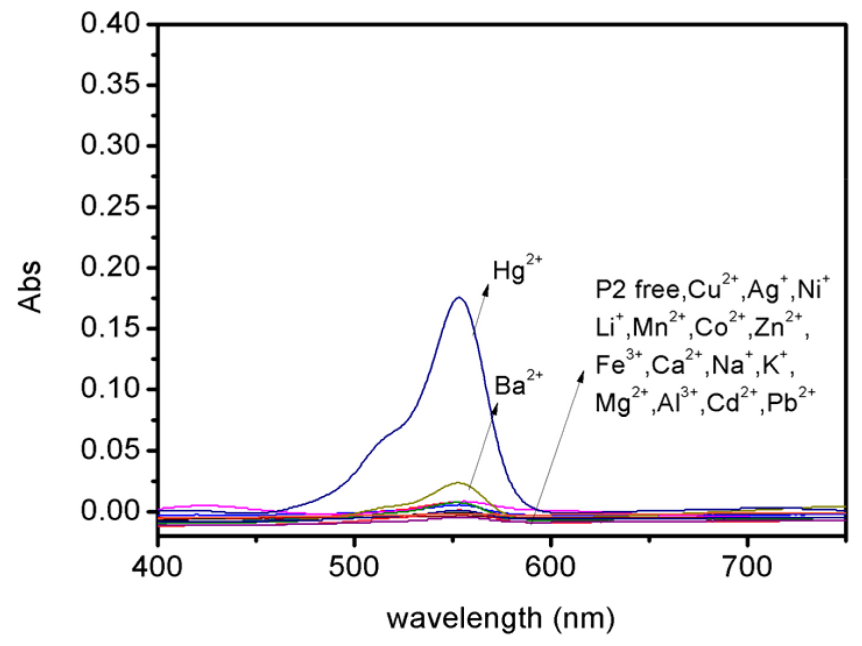

Figure 3. Absorbance spectra of $P 2(20 \mu \mathrm{mol} / \mathrm{L})$ in aqueous solution with the presence of 10 equiv. of various species

Limit detection of metal ions plays an important role in evaluating fluorescence sensor and the determination of the detection limit was calculated with Eq. DL $=3 \sigma / \mathrm{k}$. Where, $\sigma$ is the standard deviation of blank measurement and $\mathrm{S}$ is the slope from plotting the relative fluorescence intensity versus $\mathrm{Hg}^{2+}$ concentration. As shown in the Figure 4(b), as for probe P2, it demonstrates a good linear relationship (Stern-Volmer equation) between the fluorescence intensity and the $\mathrm{Hg}^{2+}$ concentration. The linear response for the fluorescence intensity response of compound $\mathrm{P} 2$ was between 0 and $1.4 \times 10^{-4} \mathrm{~mol} \mathrm{~L}^{-1}$ and the detection limit of $\mathrm{Hg}^{2+}$ was measured to be $1.7 \times 10^{-7} \mathrm{~mol} \mathrm{~L}^{-1}$, which suggests that sensor $\mathrm{P} 2$ has moderate affinity and high sensitivity for $\mathrm{Hg}^{2+}$. The association constant $\mathrm{K}$ of the complex $\mathrm{P} 2-\mathrm{Hg}^{2+}$ was then calculated to be $0.93 \times 10^{3} \mathrm{M}^{-1}$, with a linear relationship (Figure 5) by Benesi-Hildebrand method $\left(\mathrm{F}_{\mathrm{Max}}\right.$ : the maximum of fluorescence intensity when the probe $\mathrm{P} 2$ coordinates with mercury ion under the fluorescence titration experiment conditions. $\mathrm{F}_{\mathrm{Min}}$ : the fluorescence intensity of free probe $\mathrm{P} 2$ under the fluorescence titration experiment conditions), Eq. (1) $)^{37,38}$ 

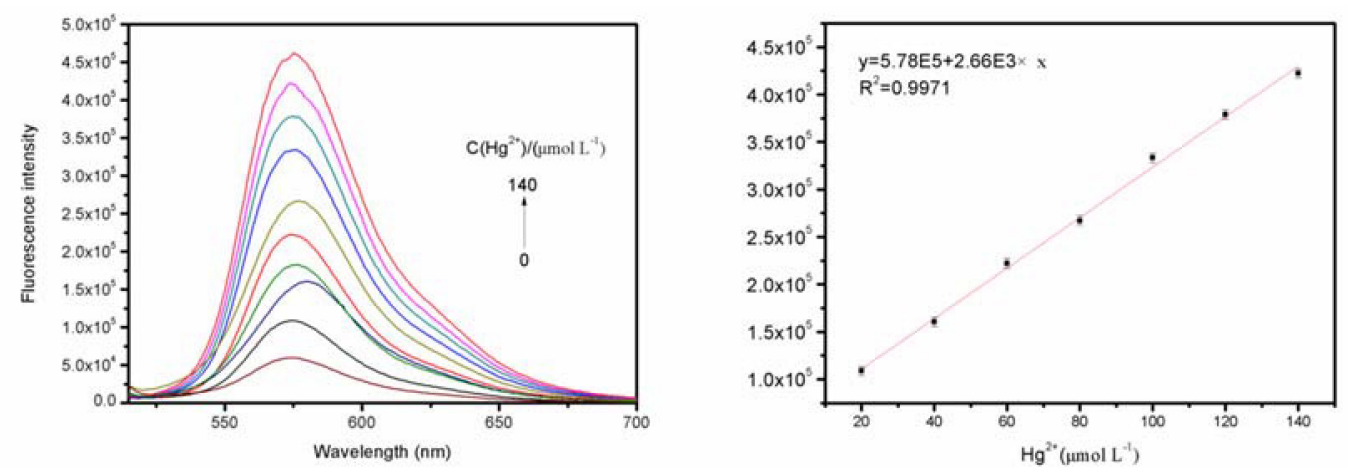

Figure 4. (a) Fluorescence intensity at $580 \mathrm{~nm}$ of $\mathrm{P} 2\left(10.0 \mu \mathrm{mol} \mathrm{L} \mathrm{L}^{-1}\right)$ in an $\mathrm{H}_{2} \mathrm{O}$ solution with different amounts of $\mathrm{Hg}^{2+}$; (b) The fluorescence intensity (at 580 nm) of compound P2 $\left(10 \mu \mathrm{mol} \mathrm{L}^{-1}\right)$ as a function of the $\mathrm{Hg}^{2+}$ concentration in aqueous solution

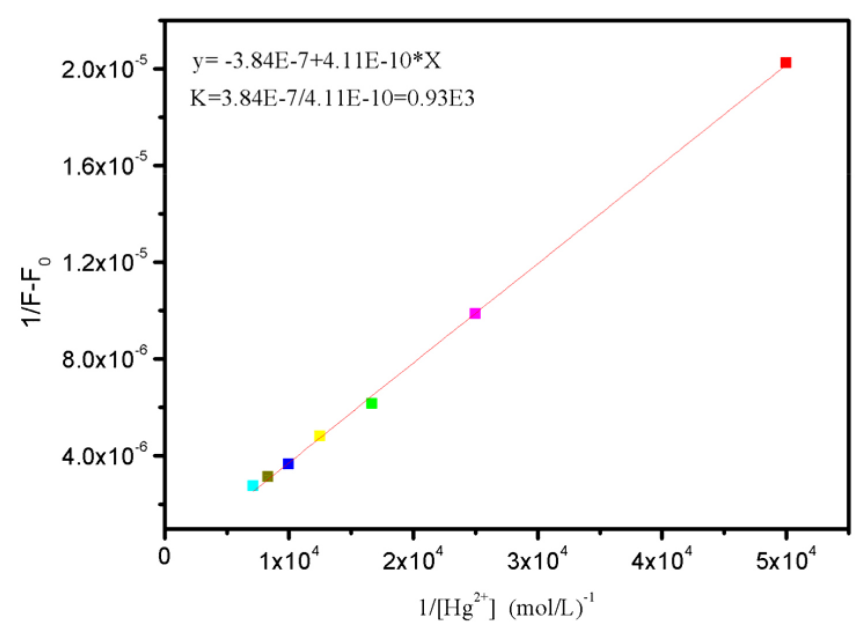

Figure 5. Benesi-Hildebrand plot $\left(\lambda_{e x}=500 \mathrm{~nm}\right)$ of P2, assuming 1:1 stoichiometry for association between $\mathrm{P} 2$ and $\mathrm{Hg}^{2+}$ in the aqueous solutions

$$
\frac{1}{F-F_{0}}=\frac{1}{K\left(F_{\text {Max }}-F_{\text {Min }}\right)\left[\mathrm{Hg}^{2+}\right]}+\frac{1}{F_{\text {Max }}-F_{\text {Min }}}
$$

\section{Responsiveness and adaptability}

The adaptability and also the responsiveness have been determined using the lifetime of the $\mathbf{P 2}$ and $\mathrm{Hg}^{2+}$ by time-resolved fluorescence spectrofluorometer and time-response plot. The fluorescence lifetime was measured at an excitation $460 \mathrm{~nm}$ of the NanoLED source. The decays of probes were found to be monoexponential. The lifetime decays in the absence of $\mathrm{Hg}^{2+}$ and in the presence of $\mathrm{Hg}^{2+}$ are shown in Figure 6. The average lifetime of P2 was $1.72 \mathrm{~ns}$ and 5.10ns $(\mathrm{XSQ}=1.31)$ while the lifetime of $\mathrm{P} 2+\mathrm{Hg}^{2+}$ was $1.74 \mathrm{~ns}$ $(\mathrm{XSQ}=1.05)$. Double exponential fitting equation was used to describe the fluorescence lifetime of probe itself, because xanthene was a chromophore which formed a conjugated system. The upper part of structure formed a plane and orthogonalized with the ring of xanthene which also can be seen as a chromophore. After adding metal ions, the upper part including carbanyl group and phenyl group do not conjugate with xanthenes, and the stereo-hindrance effect of carbanyl group limits the rotation of the benzene ring. So the major chromophore is still xanthene which used single exponential fitting equation. Time-dependence for binding of the probe P2 with $\mathrm{Hg}^{2+}$ is given in Figure 7. Following the addition of 10 equiv. $\mathrm{Hg}^{2+}$ ion to $20.0 \mathrm{mmol} \mathrm{L}^{-1}$ probe $\mathrm{P} 2$, the fluorescence intensity of probe $\mathrm{P} 2$ was turn on moderately, and reached a stable value within $20 \mathrm{~min}$.

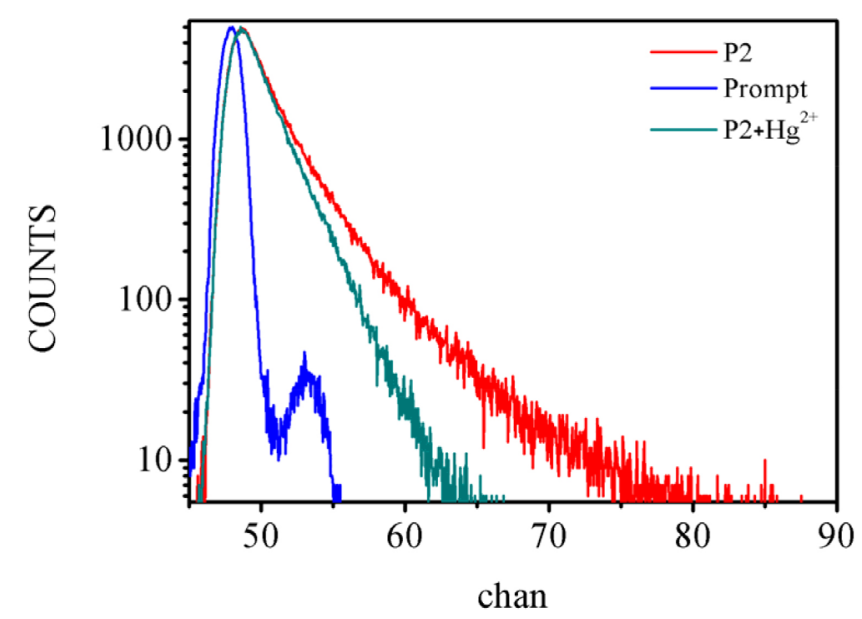

Figure 6. Fluorescence decay curves of $\mathrm{P} 2$ and $\mathrm{P} 2+\mathrm{Hg}^{2+}$ in aqueous solution obtained at $\lambda_{e x}=500 \mathrm{~nm}$

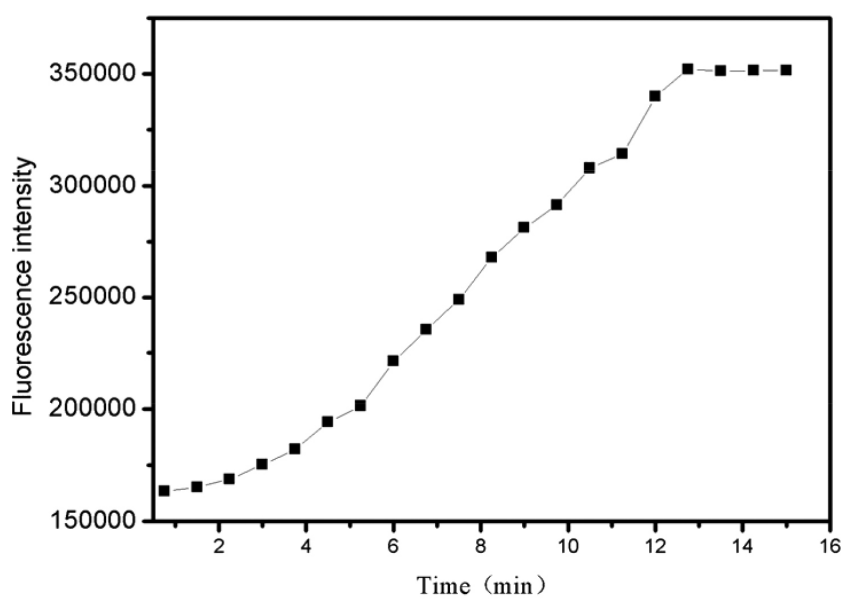

Figure 7. Fluorescence turn on profile of addition $\mathrm{Hg}^{2+}$ (1.5 equiv.) to P2(10.0 umol $\mathrm{L}^{-1}$ ) in water ( $\mathrm{pH} 7.2$ ) from 0.4 to $13 \mathrm{~min}$

To further investigate the interaction of $\mathrm{Hg}^{2+}$ and the probe $\mathrm{P} 2$, the $\mathrm{Hg}^{2+}$ binding stoichiometry of the probe can be determined from the Job plot. It is obvious in the Figure 8 that the fluorescence intensity reached a maximum when the ratio was 0.5 , which suggesting that a 1:1 stoichiometry of the $\mathrm{Hg}^{2+}$ to the probe in the complex. And we also explore the effect of $\mathrm{pH}$ on the chemosensor response as shown in Figure 9. 


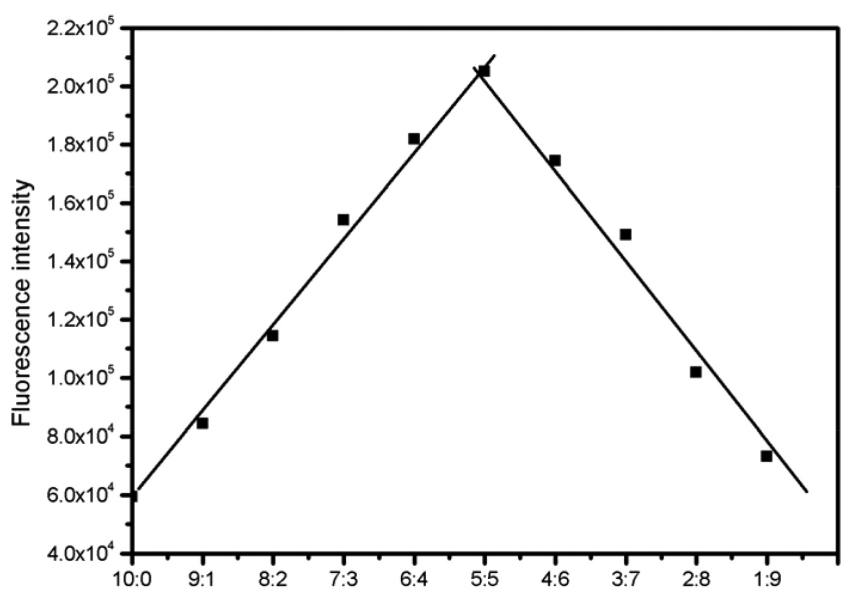

Figure 8. Job's plot of the complexation between $\mathrm{P} 2$ and $\mathrm{Hg}^{2+}$, total concentration of $\mathrm{P} 2$ and $\mathrm{Hg}^{2+}$ is $20.0 \mu \mathrm{mol} \mathrm{L} \mathrm{L}^{-1}$

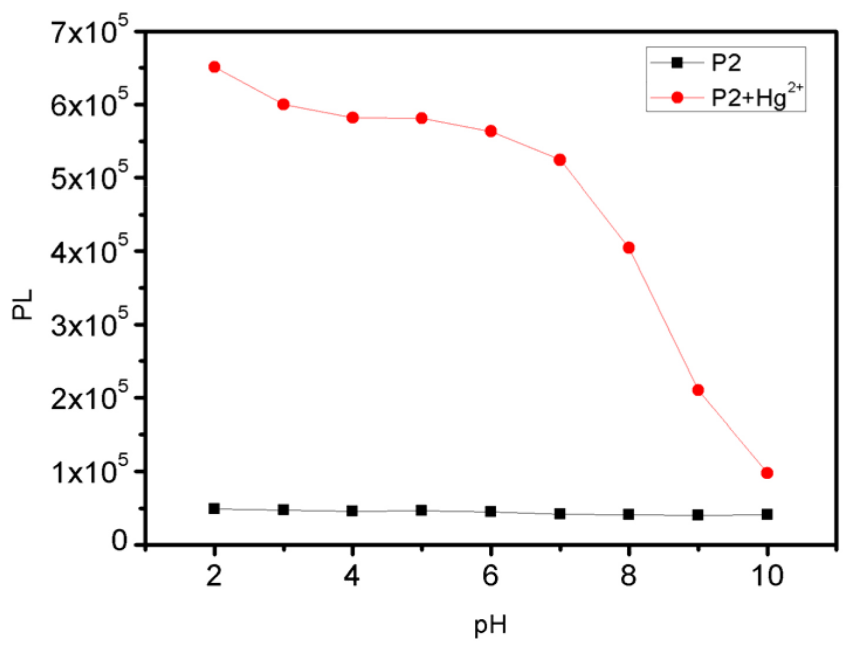

Figure 9. Fluorescence intensity $(580 \mathrm{~nm})$ of free chemosensor P2 $\left(10 \mu \mathrm{mol} \mathrm{L} \mathrm{L}^{-1}\right)$ and in the presence of 10 equiv. $\mathrm{Hg}^{2+}$ in aqueous solutions with different $p H$ conditions
Table 1. Determination of $\mathrm{Hg}^{2+}$ concentrations in water samples

\begin{tabular}{lccc}
\hline Sample & $\begin{array}{c}\mathrm{Hg}^{2+} \text { added } \\
(\mu \mathrm{mol} / \mathrm{L})\end{array}$ & $\begin{array}{c}\mathrm{Hg}^{2+} \text { found } \\
(\mu \mathrm{mol} / \mathrm{L})\end{array}$ & Recovery \\
\hline Tap water & 0 & 0 & \\
& 25 & 21.5 & $86 \%$ \\
& 50 & 45.6 & $91.2 \%$ \\
\hline
\end{tabular}

\section{APPLICATION AND MECHANISM}

In order to explore its practicality in real samples, we selected probe $\mathrm{P} 2$ in a standard addition method to determine the mercury ion in water tap from our lab. No fluorescence enhancement was observed when the tap water existed only. When the tap water were spiked with different concentrations of mercury ion $\left(0 \mu \mathrm{mol} \mathrm{L} \mathrm{L}^{-1}\right.$, $25 \mu \mathrm{mol} \mathrm{L}-1,50 \mu \mathrm{mol} \mathrm{L}{ }^{-1}$ ) and measured with the methods above, mercury recoveries were about $88.0 \%$ (Table 1 ).

From the molecular structure and spectral results of P2, a fluorescent chemosensor for $\mathrm{Hg}^{2+}$ was constructed as shown in Figure 10. It can be concluded from the figure after the addition of the $\mathrm{Hg}^{2+}$ ion induced a ring opening of the spirolactam of rhodamine took place.

\section{CONCLUSIONS}

In summary, a water-soluble fluorescent sensor P2 for mercury ion has been designed and synthesized. This probe display 1:1 complex formation with mercury ion which could be monitored by the spectral changes as well as color changes. It showed high sensitivity and selectivity for $\mathrm{Hg}^{2+}$ recognition in comparison to other metal ions in pure aqueous solution. Especially, it should be noted that these fluorescence experiments were performed in a pure aqueous solution, which is different from other probes determined in organic solvent or mixed solutions. Based on these conditions, this senor show a great potential in the detection and analysis of diverse mercury-related cases in biological, medical and environmental areas.

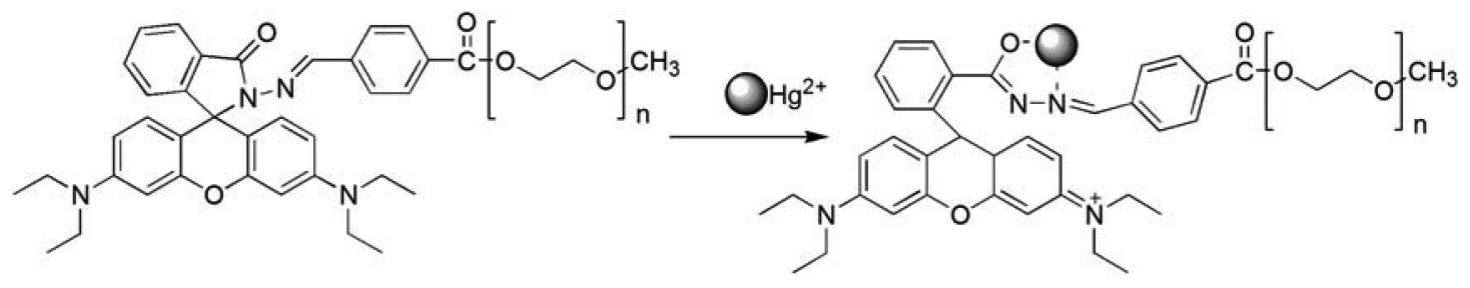

Figure 10. Possible sensing mechanism of $\mathrm{P} 2$ with $\mathrm{Hg}^{2+}$

\section{SUPPLEMENTARY MATERIAL}

Figures $1 \mathrm{~S}$ to $5 \mathrm{~S}$ are available for download at http://quimicanova. sbq.org.br in pdf format with free access

\section{ACKNOWLEDGEMENTS}

This work was supported by the Fundamental Research Funds for the Central Universities (KYLX15_0125) and National Major Scientific Instruments and Equipment Development Projects (2014YQ060773) and A Project Funded by the Priority Academic Program Development of Jiangsu Higher Education Institutions
(1107047002) and Policy Guidance Program (Research Cooperation)-Prospective Joint Research Project (BY2016076-02)

\section{REFERENCES}

1. Boening, D. W.; Chemosphere 2000, 40, 1335

2. Nolan, E. M. ; Lippard, S. J.; Chem. Rev. 2008, 108, 3443.

3. Nolan, E. M. ; Lippard, S. J.; J. Am. Soc. 2003, 125, 14270.

4. Wang ,C. ; Wong, K. M.; Inorg. Chem. 2013, 52, 13432.

5. Clarkson, T. W.; Magos, L.; Myers ,G. J.; New. Engl. J.Med. 2003, 349, 1731.

6. Llobet, J.; Falco, G.; Casas, C.; Teixido, A. ; Domingo, J.; J. Agr. Food. Chem. 2003, 51, 838 . 
7. Suresh, M.; Shrivastav, A.; Mishra, S.; Suresh E.; Das, A.; Org. Lett. 2008, 10, 3013.

8. Chen,Y.; Han, K. Y. ; Liu,Y.; Bioorg. Med. Chem. 2007, 15, 4537.

9. Roy, P.; Dhara, K. ; Manassero, M.; Ratha, J. ; Banerjee, P.; Inorg. Chem. 2007, 46, 6405.

10. Royzen, M.; Durandin, A. ; Young, V. G.; Geacintov, N. E. ; Canary, J. W.; J. Am. Soc. 2006, 128, 3854.

11. Banerjee, A.; Sahana, A.; Das, S.; Lohar, S.; Guha, S.; Sarkar, B.; Mukhopadhyay, S. K.; Mukherjee A. K.; Das, D.; Analyst 2012, 137, 2166.

12. Ding, P.; Wang, J.; Cheng, J.; Zhao, Y.; Ye, Y.; New. J. Chem. 2015, 39, 342.

13. Lee, H. Y.; Swamy, K.; Jung, J. Y.; Kim , G.; Yoon, J.; Sens. Actuators, B 2013, 182, 530 .

14. Sen, S.; Mukherjee, T.; Chattopadhyay, B.; Moirangthem, A.; Basu, A.; Marek, J.; Chattopadhyay, P.; Analyst 2012, 137, 3975.

15. Patil, R.; Moirangthem, A.; Butcher, R.; Singh, N.; Basu, A.; Tayade, K.; Fegade, U.; Hundiwale, D.; Kuwar, A.; Dalton Trans. 2014, 43, 2895.

16. Haugland, R. P.; The handbook: a guide to fluorescent probes and labeling technologies, Invitrogen Corp.: Carlsbad, 2005.

17. Huang, J.; Xu, Y.; X. Qian; Org. Chem. 2009, 74, 2167.

18. Suresh, M. ; Mishra, S.; Mishra, S. K.; Suresh, E.; Mandal, A. K.; Shrivastav, A.; Das, A.; Org. Lett. 2009, 11, 2740.

19. Zhou,Y. ; Wang, F.; Kim, Y.; Kim, S. J.; Yoon, J.; Org. Lett. 2009, 11, 4442.

20. Du, J.; Fan, J.; Peng, X.; Sun, P.; Wang, J.; Li, H.; Sun, S.; Org. Lett. 2010, 12, 476.
21. McClure, D. S.; J. Chem. Phys. 1952, 20, 682.

22. Suresh, M. ; Ghosh, A.; Das, A.; Chem. Commun. 2008, 33, 3906.

23. Renzoni, A. ; Zino, F.; Franchi, E.; Environ. Res. 1998, 77, 68.

24. Kumar, K. S.; Ramakrishnappa, T.; Balakrishna, R. G.; Pandurangappa, M.; J. Fluoresc. 2014, 24, 67.

25. Dong, Z.; Tian, X.; Chen,Y.; Hou, J.; Guo,Y.; Sun, J. ; Ma, J.; Dyes Pigm. 2013, 97, 324.

26. Yang , B.; Wu, W.; The Imaging Science Journal 2013, 31, 421.

27. Zhang, Y.; Shi, B.; Zhang, P.; Huo, J.; Chen, P.; Lin, Q.; Liu , J. ; Wei, T.; Sci. China Chem. 2013, 56, 612.

28. Wang, L.; Zheng, B.; Zhao, Y.; Du, J. ; Xiao, D.; Anal. Methods 2012, 4, 2369.

29. Molineux, G.; Cancer. Treat. Rev. 2002, 28, 13.

30. Fruijtier-Pölloth, C.; Toxicology 2005, 214, 1.

31. Feng, L.; Yang, X.; Shi, X.; Tan, X.; Peng, R.; Wang, J.; Liu, Z.; Small 2013, 9, 1989.

32. Vanin, F.; Sobral, P.; Menegalli, F.; Carvalho, R.; Habitante, A.; Food Hydrocolloids 2005, 19, 899.

33. Dujols, V.; Ford, F.; Czarnik, A. W.; J. Am. Soc. 1997, 119, 7386.

34. Yang, X. F.; Guo, X. Q.; Zhao, Y. B.; Talanta 2002, 57, 883.

35. Geng, T.; Huang, R.; Wu, D.; RSC Adv. 2014, 4, 46332.

36. Xiang, Y.; Mei, L.; Li, N.; Tong, A.; Anal. Chim. Acta 2007, 581, 132.

37. Liu, Y. J.; Chao, H.; Yao, J. H.; Li, H.; Yuan, Y. X.; Ji, L. N.; Helv. Chim. Acta 2004, 87, 3119.

38. Yan, L.; Zhou, Y.; Du, W.; Kong, Z. ; Qi, Z.; Spectrochim. Acta, Part A 2016, 155, 116. 